\title{
East European U3As facing the problem of seniors' needs
}

\author{
Aleksander Kobylarek \& Kamil Błaszczyński
}

\begin{abstract}
The development of Universities of the Third Age in Central and Eastern Europe progressed in a specific manner, and was only partially inspired by the changes occurring in adult education in other parts of the world. Affected by various historical determinants in this part of Europe, a specific model of the U3A was created, embracing holistic and flexible education. This article presents the results of research into the various needs of U3A students in Poland, Belarus and Ukraine. Selected needs were analysed, as well as how they manifest themselves in each of those countries. The research was conducted by interview-questionnaire on 515 U3A students during 2015-6. The research results show that the developmental needs of U3A students are different in different countries. It could also be presumed that the holistic model of the U3A works well in various cultural environments and under varied conditions.
\end{abstract}

Key words:

U3A; senior aging society; gerontology, seniors' needs; educational needs 


\section{UTI da Europa de Leste face ao problema das necessidades dos seniors}

Resumo: As Universidades da Terceira Idade na Europa Central e Oriental desenvolveram-se de uma maneira específica e foram parcialmente inspiradas pelas mudanças que ocorreram na educação de adultos, em outras partes do mundo. Nesta parte da Europa, afetada por vários determinantes históricos, foi criado um modelo específico para as Universidades da Terceira Idade, baseado num tipo de educação holística e flexível. Este artigo apresenta os resultados de pesquisas efetuadas sobre as várias necessidades dos estudantes das Universidades da Terceira Idade, na Polónia, Bielorrússia e Ucrânia. As necessidades selecionadas foram analisadas bem como a forma como se manifestam em cada um destes países. Foi aplicado um questionário a 515 estudantes das Universidades da Terceira Idade, durante o período 2015-2016. Os resultados da pesquisa mostram que as necessidades de desenvolvimento dos estudantes das Universidades da Terceira Idade são diferentes em diversos países. Também se poderá presumir que o modelo holístico das Universidades da Terceira Idade funciona bem em vários ambientes culturais e sob condições variadas.

Palavras-chave: universidades da terceira idade; seniors; gerontologia; necessidades dos seniores.

\section{Les UTA d'Europe de l'Est face au problème des besoins des seniors}

Résumé: Le développement des universités du troisième âge en Europe centrale et en Europe de l'Est a progressé de manière spécifique, et n'a été que partiellement inspiré par les changements intervenus dans l'éducation des adultes dans d'autres parties du monde. Influencé par divers facteurs historiques déterminants dans cette partie de l'Europe, un modèle spécifique d'U3A a été créé, adoptant une éducation holistique et flexible. Cet article présente les résultats de recherche sur les différents besoins des étudiants de l'U3A en Pologne, en Biélorussie et en Ukraine. Les besoins sélectionnés ont été analysés, ainsi que la manière dont ils se manifestent dans chacun de ces pays. La recherche a été menée par des questions d'entretien sur 515 étudiants de l'U3A au cours de l'année 2015-6. Les résultats de la recherche montrent que les besoins de développement des étudiants U3A sont différents dans les différents pays. On peut également supposer que le modèle holistique de I'U3A fonctionne bien dans divers environnements culturels et dans des conditions variées.

Mots clés: U3A ; seniors ; gérontologie ; besoins des seniors ; besoins éducatifs

\section{U3E de Europa del Este que enfrentan el problema de las necesidades de las personas mayores}

Resumen: El desarrollo de las Universidades de la Tercera Edad en Europa Central y Oriental progresó de manera específica, y solo se inspiró parcialmente en los cambios que ocurren en la educación de adultos en otras partes del mundo. Afectado por varios determinantes históricos en esta parte de Europa, se creó un modelo específico de la U3A, que abarca la educación holística y flexible. Este artículo presenta los resultados de la investigación sobre las diversas necesidades de los estudiantes de U3A en Polonia, Bielorrusia y Ucrania. Se analizaron las necesidades seleccionadas, así como la forma en que se manifiestan en cada uno de esos países. La investigación se realizó mediante un cuestionario de entrevista en 515 estudiantes de la U3A durante 2015-6. Los resultados de la investigación muestran que las necesidades de desarrollo de los estudiantes de U3A son diferentes en diferentes países. También se podría suponer que el modelo holístico de la U3A funciona bien en diversos entornos culturales y en condiciones variadas.

Palabras clave: U3A; personas mayores; gerontologia; necesidades de personas mayores; necesidades educativas 


\section{The development of the U3A in Central and Eastern Europe}

For the purposes of this article, the University of the Third Age is understood as an educational institution created to satisfy the developmental needs of older people (over 60 years of age). The research was conducted among U3As which implement the same holistic model of education (Kobylarek, 2018).

The U3As of Central and Eastern Europe are characterised by a large degree of diversification and at the same time by the appearance of characteristics common to them all. To a certain extent this is partly due to specific historical determinants, and partly to the needs and expectations of the senior students themselves. The inspiration provided by Polish experiments in this field is of particular significance in countries of the former Soviet Union (Kobylarek, 2018).

The first Universities of the Third Age were established in Western Europe relatively early in 1973 and 1974, as the first in the world, but alredy by the middle of the 1970s this type of institution was also functioning in Poland (Konieczna-Woźniak, 2001). Thus, they were among the first in the world. Educational centres established in Warsaw (1975) and Wroclaw (1976) played a leading role, and initially became the inspiration for the establishment of other centres of learning for seniors (Bilewicz, 2001). Similar initiatives did not appear in Central and Eastern Europe until the 1980s and 1990s, in Germany, the Czech Republic and Slovakia. (Shromáždilová, 2010; Hrapková, 2010). This is attested to by the structure and administration of U3As operating in the region. Before the political changes which occurred from 1989 onwards, the French model of the U3A was dominant in Poland because other possibilities were somewhat limited. For example, there were no non-governmental organizations, and the only independent organizations were connected with the Church. Before the fall of communism, all aspects of society and its institutions was centralized and controlled by members of the Communist Party, and the limited flow of information from beyond the Iron Curtain meant that there was also no inspiration for creating new solutions in adult education, such as had occurred in Great Britain and Australia, where completely new models of the U3A were created (Formosa, 2014).

Just as in Western Europe, U3As in Central and Eastern Europe often come together in national federations, which enable them to better represent the community of senior students and more effectively exert influence on the subject, The possibility of forming federations and associations is also an effect of political changes in this part of Europe, which the newly created U3As providently took advantage of, often with reference to the English tradition in this field.

The strength and activeness of Eastern European U3As deserve special attention. Their representatives can be found in international organizations representing the interests of senior students, such as AIUTA and EFOS. The representatives were mostly 
students of the U3A or managers supported by student self-governments. They also attempt to diversify their sources of funding by obtaining grants from European Union programmes dedicated to the education of seniors (Sokrates, Grundvig and Erasmus+). These U3As are generally managed by highly motivated enthusiasts, for whom co-operation with numerous entities in the local community is something natural and obvious. Thus, they become initiators in a co-operative network extending the concept of the university, and a link between scientific institutions and the local community (Kobylarek 2017).

Polish U3As occupy a special place among other institutions of a similar type offering education for seniors, because they have aided the development of similar centres in Eastern Europe (particularly Lithuania, Ukraine and Belarus). Their activity has been twofold. Since the 1990s the Mokotowski U3A in Warsaw has promoted the education of seniors in countries to the east of Poland, either by assisting the existing Polish U3As there or by establishing new ones. These are centres supporting the education of Polish seniors, who form an ethnic minority in those countries. From 2010 to 2016 the U3A in Wroclaw, thanks to funding from the Polish-American Freedom Foundation, has established and helped to develop several U3As in western Ukraine (two in Lviv and one each in Chernivtsi, Lutsk, Stryi and Ivano-Frankivsk) and also in Belarus (Grodno and Kobryn), where there were strong organizations which could support the longstanding activity of the new educational centres.

To summarise, the development of Eastern European U3As has hitherto taken place in three phases:

- From the middle 1970s - the creation of U3As based on the French model in some countries in the region, independently of each other (first Poland and then the Czech Republic, Slovakia and Slovenia).

- From the 1990s - the establishment of U3As in Ukraine, Russia and Belarus, partially independent and partially inspired by the Polish model, and also the first attempts at international co-operation through workshops and conferences.

- From 2010 - the establishment of U3As in Belarus and Ukraine, inspired by the U3A in Wroclaw. Intensive activity of federations, bringing together U3As in each country. Key to the spectacular success in propagating the concept of the U3A in Eastern Europe have been active and visionary leaders/ volunteers, who at the time saw a chance for the development of the institution on an international scale, and an opportunity to meet the needs of the region's adults seeking self-fulfillment after retirement. It would appear that the natural consequence of further development of U3As will be the creation of an international co-operative network of new federations. However, a key question still remains as to what specific needs existing U3As are addressing. Without answering this question it would be difficult to map out the further development of this type of institution. We would remain in the sphere of theoretical solutions 
(Marcinkiewicz, 2011), describing only the difficulties of carrying out research among seniors (Jakubowska, 2012).

\section{Developmental needs of seniors}

Generally, researchers have treated the problem of seniors needs in relation to specific contexts (Pekmezaris, et al. 2013), or have concentrated on more general solutions (Duay \& Bryan, 2008). At the same time, the developmental needs of seniors is a fairly specific subject, worthy of research, and is possibly best represented in such characteristic learning communities as the U3A.

If we assume that the basic conditions for successful ageing (understood as good state of physical health, psychological wellbeing and financial security) have been fulfilled, there remains the question of two basic concepts of old age - active aging and disengagement (Istance, 2015).

Accepting the disengagement theory of aging (Cummning \& Henry, 1961) means simultaneously expressing doubts as to the existence of developmental needs among the elderly and agreeing to the perception of seniors as passive, concentrated above all on their basic existential needs. Withdrawal means limited social contact and the elimination of developmental stimuli from the outside world. Research so far carried out indicates rather a deepening of the various problems experienced by older people who withdraw from social life and limit their physical activity - withdrawal is not a condition for a peaceful old age, but instead generally leads to a weakening of the organism and premature death. This is evidenced, for example, by the abnormally high death rate among men in retirement. This is particularly relevant to men because they generally experience an uncomfortable retirement through losing their professional position, which had earlier been something which defined their masculinity and social status (Borysławski, 2010) .

If we assume that a condition for successful ageing is activeness and engagement among the elderly, it would be useful to define those factors which are conducive to the engagement of seniors in social life and their personal development. At the same time we can accept as a certainty that the elderly also develop, although this development has a somewhat different character to that in younger generations. In the case of physical development seniors should try to keep in condition, and in the sphere of intellectual development structure their biographical experiences and exercise their mind through inter-system thinking (Labouvie-Vief, 2006), which often takes on a contemplative character. However, this does not mean isolation but quite the opposite. It means taking on challenges and actively participating in the local community in the role of an experienced authority, willing to help others through their knowledge. 
The ideal conditions for such a concept of development are created by leaders and managers of U3As, especially those in Eastern Europe, which aim for a holistic education embracing all aspects of human development. By offering a varied education programme, they attempt to meet the often changing expectations of senior students. At the same time this varied programme is conducive to forming educational challenges for each student. Seniors who enjoy relatively good health and financial security are able to consider developing their interests and multi-faceted education, the intrinsic aim of which is simply self-realisation (Ziębińska, 2010).

Józef Kozielecki (2000) describes this type of need as hubristic, and links it to a sense of needing to cross developmental boundaries, to educate oneself and also the pleasure of learning. Generally, the majority of lessons in the U3As are optional, and only a small number of institutions of this type conduct compulsory lessons for their students. This model meets the expectations of seniors, because their needs are varied. It is not possible to draw up just one educational programme which is equally suitable for all seniors, because their needs are varied. A flexible approach, allowing interested students to choose from a wide range of courses, appears to be the best solution. This is particularly important in the intellectual sphere, which has been formed differently in each individual student. Additionally, these students have varied forms of formal education and biographical experiences, which contribute to their informal knowledge. By preparing a wide and varied educational programme composed of a wide range of courses, U3As provide the possibility of satisfying totally different developmental needs. On the other hand, seniors can feel as if they are in a real university, dedicated to reflection and a deepening of the knowledge and wisdom which we usually associate with old age.

Although U3As in Ukraine and Belarus were inspired by the Polish model, developed by the U3A at the University of Wroclaw, there is the possibility that the needs of senior students in each of these countries varies. The antithesis is that there is no difference between the developmental needs of seniors, in that all of them are looking for the same thing from the U3A. In this case, the needs of senior students in each country should not be significantly different. So the main research question will be: In which areas are the needs of senior students in Eastern European U3As different? On the one hand, all the countries researched use the same model of U3A, with similar management and similar syllabuses and educational programs (Kobylarek, 2018). On the other hand, a distinguishing feature is nationality, which may have some effect in varying the needs and expectations of senior students. 


\section{Method}

The analyses of U3A seniors' needs have been based on Murray's Manifest Needs system.

From among the many available theories used in researching developmental needs (Maslow, Alderfer, Kozielecki), the one chosen was a concept which possesses extensive tools with a long tradition, translated into Polish (Siek, 1993). This choice was dictated primarily because of the availability of appropriate research tools, and also its coherency and pertinence to the problems under consideration, because some of the needs defined in this concept have a direct co-relation with the declarations of seniors themselves as to the reasons for participating in the U3A (Ziębińska 2010).

The original inventory consists of 195 questions, divided into 17 sub-scales, measured on the 4-point Likert scale (1 - definitely no, 2 - no, 3 - yes, 4 - definitely yes). For the purpose of the study only 5 out of the 17 sub-scales have been used: compensation, succorance, nurturance, affiliation and cognizance (hereafter called developmental needs).

Among the most frequently mentioned motives expressed by senior participants of the U3A are :

- working with others ('affiliation', according to Murray)

- achieving something in life ('compensation')

- helping and supporting other ('nurturance')

- accepting care, support and help ('succorance’)

- learning, developing interests, and gratifying curiosity ('cognizance')

(Ziębińska, 2010)

The compensation $(a=0,62)$, succorance $(a=0,67)$, nurturance $(a=0,70)$, affiliation $(a=0,69)$ and cognizance $(a=0,65)$ subscales consisted of 10 items each. Cronbach's Alpha test results of the chosen Murrays Motivation and Need system inventory proved their reliability.

In attempting to verify the hypothesis that developmental needs are differently satisfied by U3As in the countries under discussion, a series of tests (Statistica 13) on standardized data were conducted. The single factor ANOVA test has been conducted to diagnose whether there are any significant differences in needs between seniors fin the different countries. The correlation r-Pearson test was used to verify the strength and direction of connection between nationality and developmental needs. Logistical regression models were used to verify which of diagnosed needs were the best predictors of the nationality of seniors. If any significant differences have been noted they have been tested and measured with $\eta^{2}$, Cohen's $d$ effect size and Wilks $\wedge$. 


\section{Results}

515 U3A seniors participated in the study, of whom 234 were from Poland, 178 from Ukraine and 103 from Belarus universities. All active U3As in Ukraine and Belarus were researched, whereas in Poland, due to the large number of active U3As, the research was restricted to those in Lower Silesia. Those seniors who agreed to take part filled in a pen and paper test, translated into their native language - Polish, Belarussian and Ukrainian. The data collected was then subjected to the following statistical analysis.

The comparative analysis $(p=.05, a=95 \%)$, carried out with single factor ANOVA test, revealed that the main effect of nationality on needs was significant $(F(10$, 1016)=7.07, $\left.p=.000, \wedge=.87, \eta^{2}=.06\right)$, and also the Wilks $\wedge$ results indicated that the proposed 5 -elemental configuration of needs indicated rejection of a null hypothesis. Further intergroup analysis revealed significant effects for compensation ( $F(2$, $\left.512)=3.65, p=.027, \eta^{2}=.01\right)$, nurturance $\left(F(2,512)=16.88, p=.000, \eta^{2}=.06\right)$, affiliation $\left(F(2,512)=3.22, p=.040, \eta^{2}=.01\right)$ and cognizance $\left(F(2,512)=4.87, p=.008, \eta^{2}=.02\right)$. The main effect of nationality was not significant for succorance $(F(2,515)=1.04, p=n . s)$. The results obtained thus confirmed the significant main effect of nationality, and mostly significantly differences between the needs of Polish, Ukrainian and Belarusian seniors (see Table 1 for Means).

Table 1. Comparison of Needs, Stress, Self-Efficacy and Life Satisfaction Scores by Nationality

\begin{tabular}{l|cc|cc|cc}
\hline \multirow{2}{*}{} & \multicolumn{2}{|c|}{ Poland } & \multicolumn{2}{c|}{ Ukraine } & \multicolumn{2}{c}{ Belarus } \\
\cline { 3 - 6 } Compensation & Mean & SD & Mean & SD & Mean & SD \\
Succorance & $24,51 a$ & 3,22 & $23,74 a$ & 3,30 & 24,60 & 3,11 \\
Nurturance & 26,24 & 4,19 & 26,76 & 3,98 & 26,21 & 3,54 \\
Affiliation & $32,72 a$ & 3,48 & $31,01 a$ & 3,15 & $30,98 a$ & 3,41 \\
Cognizance & $29,65 a$ & 3,56 & $28,75 a$ & 3,78 & 29,59 & 4,12 \\
\hline
\end{tabular}

Note: a significant differences for $\mathrm{p}<0.05$

Post-hoc tests conducted with the RIR Tukey test revealed significant differences of compensation level between Polish and Ukrainian seniors, nurturance level between Polish and Ukrainian and Polish and Belarusian seniors, affiliation level between Polish and Ukrainian seniors, and cognizance level between Ukrainian and Belarusian seniors.

From the results obtained it is possible to discern a visible tendency implying that the most significant differences in the level of needs was between Polish and other 
Eastern European seniors. Ukrainian and Belarusian seniors appear to be more homogeneous in this regard.

The results of the $r$-Pearson test $(a=95 \%)$ indicated that there was a significant $(p<.05)$ positive correlation between all diagnosed needs (see Table 2 for details). The test results showed that correlation strength between needs varied greatly, and that nationality was a significant moderator in this regard.

Table 2. Comparison of Correlation Scores Matrixes of Needs and Life Quality Indicators by Nationality

\begin{tabular}{|c|c|c|c|c|c|}
\hline & & Succorance & Nurturance & Affiliation & Cognizance \\
\hline \multirow[t]{4}{*}{ General } & Compensation & .31 & .39 & .41 & .52 \\
\hline & Succorance & & .32 & .43 & .42 \\
\hline & Nurturance & & & .58 & .48 \\
\hline & Affiliation & & & & .52 \\
\hline \multirow[t]{4}{*}{ Poland } & Compensation & .27 & .37 & .35 & .49 \\
\hline & Succorance & & .31 & .45 & .36 \\
\hline & Nurturance & & & .53 & .42 \\
\hline & Affiliation & & & & .51 \\
\hline \multirow[t]{4}{*}{ Ukraine } & Compensation & .44 & .39 & .47 & .53 \\
\hline & Succorance & & .53 & .58 & .59 \\
\hline & Nurturance & & & .66 & .59 \\
\hline & Affiliation & & & & .57 \\
\hline \multirow[t]{4}{*}{ Belarus } & Compensation & .21 & .43 & .36 & .54 \\
\hline & Succorance & & n.c & .21 & .31 \\
\hline & Nurturance & & & .63 & .53 \\
\hline & Affiliation & & & & .45 \\
\hline
\end{tabular}

Notes: Results only significant for $p<0.05$, n.c - no correlation

Analysis of Cohen's d effect size of nationality for noted correlations between needs indicated several small or medium effects (see Table 3 for details). From the scores obtained, it is possible to state that there are minor but constant general differences between Polish and Ukrainian seniors, and that there are major specific differences between Ukrainian and Belarusian seniors in regard to succorance. 
Table 3. Cohen's d Effect Size Correlation Matrix Comparison by Paired Nationalities

\begin{tabular}{ccccc}
\hline Corelated Variables & PvU & PvB & UvB \\
Compensation & Succorance & .19 & n.e & .26 \\
& Nurturance & n.e & n.e & n.e \\
& Affiliation & .14 & n.e & .13 \\
& Cognizance & n.e & n.e & n.e \\
\hline Succorance & Nurturance & .27 & .21 & .48 \\
& Affiliation & .18 & .27 & .45 \\
& Cognizance & .30 & n.e & .36 \\
\hline Nurturance & Affiliation & .20 & .15 & n.e \\
& Cognizance & .23 & .14 & n.e \\
\hline Affiliation & Cognizance & n.e & n.e & .16 \\
\hline
\end{tabular}

Legend: PvU-Poland vs Ukraine; PvB-Poland vs Belarus; UvB-Ukraine vs Belarus

The results of binary logistic regression analysis with regard to Polish seniors (1 Polish, 0 - non-Polish) indicate that there is a significant association between nationality and developmental needs $(x 2(5)=46.70, p=.000)$. Individual predictor analyses have been examined and indicate that succorance $(t=2.15, p=.032, x 2=4.63)$ and nurturance $(t=-5.59, p=.000, x 2=33.56)$ are significant predictors in this model.

With regard to Ukrainian seniors (1 - Ukrainian, 0 - non-Ukrainian) the results indicate that there is a significant association between nationality and developmental needs $(x 2(5)=29.43, p=.000)$. Individual analysis indicates that succorance $(t=-3.54$, $\left.\mathrm{p}=.000, \quad \mathrm{x}^{2}=12.55\right)$ and nurturance $(t=-2.50, \mathrm{p}=.012, \quad \mathrm{x} 2=6.25)$ were significant predictors.

With regard to Belarusian seniors (1 - Belarusian, 0 - non-Belarusian) results indicate that there is a significant association between nationality and developmental needs $(x 2(5)=32.23, p=.000)$. Individual analysis indicates that nurturance $(t=4.56, p=.000$, $\left.x^{2}=20.77\right)$ and cognizance $(t=-3.40, p=.001, x 2=11.55)$ were significant predictors.

The data obtained allow us to state that Polish seniors may be more associated with nurturance, Ukrainian seniors may be more associated with succorance, whereas Belarusian seniors may be more associated with cognizance. Therefore, it seems that U3As can satisfy different needs of various nationalities of seniors. 
The Cohen d effect sizes, generated on a base of $x 2$ results for models, proved varied but all can be classified as significant (see Table 4 for details). The Cohens $d$ effect sizes, generated on base of $x 2$ for predictors, proved varied and for the Polish and Belarusian group (nurturance) can be classified as significant.

Table 4. Comparison of Size Effect and Ods Ratio of Needs Logistical Regression Models and Significant Predictors by Nationality

\begin{tabular}{lccc}
\hline & & $d$ & OR \\
Poland & Model & .63 & 3.13 \\
& Succorance & .19 & 1.41 \\
& Nurturance & .53 & 2.61 \\
\hline Ukraine & Model & .49 & 2.43 \\
& Succorance & .32 & 1.79 \\
& Nurturance & .22 & 1.49 \\
\hline Belarus & Model & .52 & 2.56 \\
& Nurturance & .41 & 2.10 \\
& Cognizance & .30 & 1.72 \\
\hline
\end{tabular}

Note: d Cohen size effect; OR-ods ratio

These tests provide many convincing arguments to back up the statement that nationality is a statistically significant factor which moderates the scores of seniors in developmental needs. The results indicate that seniors are not only motivated by unequally strong needs but also each national group can be distinguished by one dominant and distinctive need. Such results are undoubtedly interesting, and may suggest that U3As are very un-homogenous institutions, fulfilling different social and cultural functions.

\section{Summary}

The research results show that the University of the Third Age is an educational institution capable of attracting and satisfying people with various developmental needs. The statistical analysis also indicates that these same educational institutions for seniors, operating on the same model, are also able to address national variations in the educational and developmental needs of the elderly. Despite the fact that only a part of these needs were diagnosed (those which might show up in the U3A and can be 
researched with the aid of appropriate tools), it turns out that in each of the countries under consideration we are dealing with a preponderance of other needs among seniors. From this it could be concluded that the Eastern European model of the U3A is exceptionally well designed, capable of adapting to diverse cultural conditions and satisfying completely different developmental needs among seniors. Therefore, it is worth implementing and verifying in other countries, in that the holistic and flexible Eastern European model of adult education may be the answer to the problems of an ageing society.

Educational activeness among the elderly can be a positive alternative to passivity, which can lead to a worsening of both physical and mental health. The holistic model proposed by Eastern European U3As is sufficiently comprehensive and flexible to satisfy the varied developmental expectations of the elderly. From this it can be concluded that these particular educational institutions are ideally suited to the need to activate an ageing society. The Central and Eastern European model of the U3A, developed over the last decade, is so universal as to be able to tackle the various educational expectations of seniors, regardless of the cultural diversity within the region.

It could also be supposed that the diverse needs and expectations of seniors participating in the U3A in various countries will necessitate the further diversification of education programs. Thus, those U3As who wish to meet those needs will try to extend or change their programs. This means that in time this will most probably lead to a radical diversification in the functioning of U3As in Eastern and Central Europe, which until now have been fairly uniform.

\section{References}

Bilewicz, A. (2001). Uniwersytet Trzeciego Wieku we Wrocławiu w latach 1976-2001. [The University of the Thitd Age in Wrocław, 1976-2001] Wrocław: Studium Trzeciego Wieku.

Borysławski, K. (2010). W poszukiwaniu przyczyn starzenia się. IIn Search of the Causes of Ageing] In A. Kobylarek, \& E. Kozak, Starość u progu XXI wieku. Uniwersytety Trzeciego Wieku wobec problemów starzejącego sie społeczeństwa [Old age at the turn of the 21st century. The University of the Third Age in the face of the problems of an ageing society] (pp. 51-61). Wrocław: ARGI.

Cumming, E., \& Henry, W. E. (1961). Growing old. The process of disengagement. New York: Basic Books.

Duay, D. L., \& Bryan, V. C. (2008). Learning in Later Life: What Seniors Want in a Learning Experience. Educational Gerontology, 34, pp. 1070-1086.

Formosa, M. (2014). Four decades of Universities of the Third Age: past, present, future. Ageing \& Society, 34 (1), pp. 42-66. 
Hrapková, N. (2010). Uniwersytety Trzeciego Wieku na Słowacji. [The University of the Third Age in Slovakia] In A. Kobylarek, Starość u progu XXI wieku. Uniwerystety Trzeciego Wieku wobec problemów starzejącego się społeczeństwa [Old age at the turn of the 21st century. The University of the Third Age in the face of the problems of an ageing society] (pp. 127-130). Wrockaw: Argi.

Istance, D. (2015). Learning in Retirement and Old Age: an agenda for the 21st century. European Journal of Education (2), 225-238.

Jakubowska, L. (2012). Seniors as a research group in the experimental model. Journal of Education Culture and Society (2), 27-35.

Kobylarek, A. (2017). Polish Humboldtian University in the Face of Paradigmatic Change. Cambridge Scholars Publishing.

Kobylarek, A. (2018). The University of the Third Age in Poland. A democratic and holistic approach to the education of the elderly. Ementor (5).

Konieczna- Woźniak, R. (2001). Uniwersytety Trzeciego Wieku w Polsce. Profilaktyczne aspekty edukacji seniorów. [The University of the Third Age in Poland, Profilactic aspects of the the education of seniors] Poznań: Eruditus.

Kozielecki, J. (2000). Koncepcje psychologiczne człowieka. [The psychological concept of man] Warszawa: Żak.

Labouvie-Vief, G. (2006). Emerging Structures of Adult Thought. In J. J. Arnett, \& J. L. Tanner, Emerging Adults in America:Coming of Age in the 21st Century (pp. 173-190). Washington: American Psychological Association.

Marcinkiewicz, A. (2011). The University of the Third Age as an institution counteracting marginalization of older people. Journal of Education Culture and Society (2), 38-34.

Pekmezaris, R., Kozikowski, A., Moise, G., Peter, A. C., Hirsch, J., Kraut, J., \& Levy, L. C. (2013). Aging in Suburbia: An assessment of Senior Needs. Educational Gerontology, 39, 355-365.

Shromáždilová, L. (2010). Uniwersytet Trzeciego Wieku w Republice Czeskiej. [The University of the Third Age in the Czech Republic] In A. Kobylarek, Starość u progu XXI wieku. Uniwersytety Trzeciego Wieku wobec problemów starzejącego się społeczeństwa [Old age at the turn of the 21st century. The University of the Third Age in the face of the problems of an ageing society] (p. 126). Wroclaw: Argi.

Siek, S. (1993). Wybrane metody badania osobowości. [Selected methods of the personality research], Warszawa:Wydawnictwa Akademii Teologii Katolickiej.

Ziębińska, B. (2010). Uniwerystety Trzeciego Wieku jako instytucje przeciwdziałające marginalizacji osób starszych. [The University of the Third Age as an institution combatting the marginalisation ot the elderly] Katowice: Śląsk Wydawnictwo Naukowe. 
Aleksander Kobylarek

$\mathrm{PhD}$ in humanities, assistant professor at the University of Wrocław (Poland)

in the Institute of Pedagogy.

Email: aleksander.kobylarek@gmail.com

ORCID: https://orcid.org/0000-0002-4562-9035

Kamil Błaszczyński

$\mathrm{PhD}$, Graduate of doctoral studies in Institute of Sociology on University of Wrocław , Poland. Adjunct Professor in Institute of Political Scienceon

University of Wrocław

Email: kamil.blaszczynski2@uwr.edu.pl ORCID: https://orcid.org/0000-0003-4896-8371

Correspondência

Aleksander Kobylarek

Uniwersytet Wrocławski

Instytut Pedagogiki, ul. Dawida 1

50-527 Wrocław

Data de submissão: Janeiro 2020

Data de avaliação: Março 2020

Data de publicação: Novembro 2020 